\title{
The Effect Of Financial Distress And Disclosure On Going Concern Opinion Of The Banking Company Listing In Indonesian Stock Exchange
}

\author{
Jamaluddin M
}

State Islamic University of Alauddin Makassar

\begin{abstract}
This study aims to determine the effect of financial distress and disclosure to the going concern of banking companies listing on Indonesia Stock Exchange. Population of this research is all banking companies listed in Indonesian Stock Exchange. Sample in this research is 6 banking companies. The analysis method is logistic regression. The result of the research shows that financial distress has a negative effect on going-concern opinion, while disclosure negatively affect of going concern opinion on banking company listing in Indonesian Stock Exchange.
\end{abstract}

Keyword: Financial Distress, Disclosure, Going Concern

\section{Introduction}

Businesspeople need certainty in running their business. Certainty that is expected by the business in order to maintain and protect their business so as to maintain its sustainability. Businesses are always looking for accurate and definitive information, because that information will be used in making business considerations as well as used to make business decisions. Such information comes largely from the company's financial statements, where the financial statements will be audited by the auditor prior to publication.

The auditor plays an important role in the information published by the company. Both the poor quality of the information presented depends heavily on the auditor's. Auditors serve as a liaison between users of financial statements with financial report makers. The AICPA (American Institute of Certified Accountants) requires that the auditor should clearly state whether the client company can maintain its viability up to a year later after reporting. Although the auditor is not responsible for the survival of a company but in conducting the audits of survival it should be the auditor's consideration in giving an opinion.

The opinion of audit module going concern is an opinion issued by the auditor to ascertain whether the company can maintain its viability within the specified timeframe. Auditors in performing their duties, not to mention the potentially disrupt the viability of a company. The auditor should evaluate the continuity of the company at a certain time limit.

Opinion going concern is bad news for users of financial statements. Providing a going concern opinion, then the company will become bankrupt faster because many investors are canceling the investment or creditors withdraw their funds (Januarti et.al, 2008). The phenomenon that occurred in recent years is the increasing lawsuits against the accounting firm. Tucker et al. (2003) found that of 228 publicly traded firms, Enron and 95 other companies received unqualified opinions in the year prior to the bankruptcy. This fact raises the question of why a company that gets unqualified opinions suddenly stops operating.

According to (Chen and Church, 1996) that when economic conditions are uncertain, investors expect the auditor to provide an early warning of the company's financial failures. The Auditor is responsible for assessing whether there is great doubt about the company's ability to maintain its going concern within a period of not more than one year from the date of audit report.

Some research on the issue of going concern (Koh and Tan, 1999) that there is no procedure of determining the going concern status that is structured causing audit failure. Mutchler (1985) criteria the company will receive a going concern audit opinion audit if it has a problem on earnings, reorganization, inability to pay interest, received the previous year's going concern opinion, in the process of liquidation, negative capital, negative cash flow, negative operating income, negative work, 2 to 3 consecutive years of loss, and deficit. 
According to O'Reilly (2010), going concern opinion is useful for investors as a negative signal about the survival of the company. In contrast, non-going concern opinion will be considered as a positive signal for investors as a marker that the company is in good condition.

Going concern is a fundamental concept in accounting and auditing. Some researchers (Hopwood et al. 1994, Koh 1991, Levitan and Knoblett 1985, Altman 1982, and Deakin 1977 in Fanny and Saputra 2005, Ramadhany 2004, Fanny and Saputra 2005, Setyarno et al 2006, Santosa and Wedari 2007, Rudyawan and Badera 2008 , and Junaidi and Hartono 2010) suggest predictive models to help auditors make a company's going concern decision.

Financial distress is a stage of decline in a company's financial condition prior to the occurrence of bankruptcy or liquidation. Bankruptcy is also often called corporate liquidation or insolvency. Bankruptcy as a financial failure and economic failure (Ramadhani and lukviarman, 2009).

Some previous studies have concluded that bankruptcy prediction models use financial ratios more accurately than auditor opinions in grouping companies bankrupt and not bankrupt (Altman and McGough 1974). The prediction model using the financial ratios one of them is the Altman Z-Score prediction model. In 1968, Edward I. Altman developed a model for analyzing a company grouped bankrupt and did not go bankrupt using 22 financial ratios classified into five categories: liquidity, profitability, leverage, market and activity test ratios. The model was not able to be adopted for companies that do not go public, so in 1993 Altman revise the model. Altman retains five categories by substituting the market-to-market ratio with the ratio of preferred and common share book values to total debt (Fanny and Saputra 2005)

Using the revised Altman Z-Score model, companies can be grouped into bankrupt companies and not bankrupt. Companies that go bankrupt will generally experience difficulties (financial distress) before the bankruptcy occurs. Auditors need to be aware of the symptoms of financial hardship and doubt the viability of the company. Survival of the company's is an indication of bankruptcy. Altman and McGough (1974) that the predicted level of bankruptcy using a prediction model reached the level of $82 \%$ accuracy and suggested the use of the bankruptcy prediction model as an auditor tool to decide the company's ability to maintain its survival.

The signs of bankruptcy in this regard are seen using accounting data (Hanafi 2005: 263). Lenard et al. (1998) in Fanny and Saputra (2005) said that one important thing that should be decided by the auditor is whether the company can maintain its going (going concern). Sales growth shows the growth of the company's strength in its operations. Altman (1986) in Petronela (2004) suggests that companies with negative growth indicate a greater tendency toward bankruptcy so that firms whose profits will not go bankrupt. The higher company's sales growth rate, the less likely it is for an auditor to issue a going concern audit opinion.

The auditor must be competence as well as the precise attitude it has, to see the disclosure made by the company as a consideration in expressing the company's viability. Ardiani, et al (2012), Junaidi \& Jogiyanto (2010), and Haron, et al (2009), proved that the disclosure had an effect on the acceptance of going concern auditor's opinion. While Yaqin \& Sari (2015), and Arsianto \& Rahardjo (2013), proved that the disclosure has no effect.

Disclosure is one factor that is considered related to the acceptance of going concern audit opinion toward the company. Disclosure or disclosure of financial statements will facilitate the auditor in assessing the company's financial condition. Disclosure of financial statements is very important information for the auditor, for example, disclosure of financial information regarding the consistency of the use of accounting methods in the preparation of financial statements, corporate policies, corporate co-operation with related parties, and events after the balance sheet date in the provision of audit opinion going concern (Aningdita, 2013).

Adequate disclosure of the company's financial information becomes one of the bases of the auditor in giving his opinion on the fairness of the company's financial statements. This is evidenced by research conducted by Adi and Mutmainah (2012) and Verdiana (2013) who said that the disclosure positively affect the going concern audit opinion. In contrast, Haroon et al. (2009), Junaidi and Hartono (2010), and Aningdita (2013) in his research said that disclosure has a negative effect on going concern audit opinion. The higher the disclosure, the lower the company receives a going concern opinion.

\section{Material And Method}


The method in this research is quantitative research. This study uses sampling in Banking Companies listed in Indonesia Stock Exchange (BEI) in 2012 until 2016. Population is all banking company listed in Indonesia Stock Exchange. Sampling technique using purposive sampling. The sampling criterion in this research is that the banking company has been listed on Indonesia Stock Exchange from 2012 to 2016, the company issued its financial statements for the period of 2012 to 2016 in a row, the company did not experience any losses during 2012 to 2016 period, the company has audited the company's financial statements for the period of 2012 to 2016, and the company that did not change the public accounting firm during the period of change of public accounting firm in the period 2012 to 2016. Based on predetermined criteria, there are only 6 companies that meet the sample selection criteria with the observation period 5 years, so the total observation is 30 .

\section{Result}

Results of Logistic Regression

a. Model Feasibility

Analysis Hosmer and Lemeshow Goodness of Fit is used to assess the feasibility of the regression model.

Table. 1

Hosmer and Lemeshow Test

\begin{tabular}{|l|r|r|r|}
\hline Step & Chi-square & Df & \multicolumn{1}{c|}{ Sig. } \\
\hline 1 & 6.160 & & 7
\end{tabular}

If the Hosmer and Lemeshow Goodness of Fit Test value greater than 0.05 means the null hypothesis is accepted, and indicates the model is able to predict the observed value. The statistical value of Hosmer and Lemeshow Goodness of Fit is 6,160 and the probability value of significance is $0.521>0.05$. It can be concluded that the model is able to predict the value of its observation.

b. Assessing the Entire Fit Model

Assess the overall model by comparing the Log-Likelihood (-2LL) value in (Block Number 0) with the Log-Likelihood (-2LL) value in (Block Number 1).

\section{Table 2}

-2 Log Likelihood (Block Number 0)

\begin{tabular}{|ll|r|r|}
\hline & & \multicolumn{2}{|c|}{ Coefficients } \\
\cline { 3 - 4 } Iteration & -2 Log likelihood & \multicolumn{2}{|c|}{ Constant } \\
\hline Step 0 & 1 & 32.679 & 1.067 \\
& 2 & 32.596 & 1.186 \\
& 3 & 32.596 & 1.190 \\
& 4 & 32.596 & 1.190 \\
\hline
\end{tabular}


Table 3

-2 Log Likelihood (Block Number 1)

\begin{tabular}{|c|c|c|c|c|}
\hline \multirow[b]{2}{*}{ Iteratio } & & \multirow[b]{2}{*}{-2 Log likelihood } & \multicolumn{2}{|c|}{ Coefficients } \\
\hline & & & Constant & DICLOSUR \\
\hline \multirow[t]{8}{*}{ Step 1} & 1 & 24.326 & 32.106 & -.391 \\
\hline & 2 & 20.009 & 63.448 & -.777 \\
\hline & 3 & 18.073 & 98.171 & -1.205 \\
\hline & 4 & 17.514 & 126.948 & -1.558 \\
\hline & 5 & 17.453 & 140.102 & -1.719 \\
\hline & 6 & 17.452 & 141.895 & -1.741 \\
\hline & 7 & 17.452 & 141.923 & -1.741 \\
\hline & 8 & 17.452 & 141.923 & -1.741 \\
\hline
\end{tabular}

The Log Likelihood (-2LL) statistic value in (Block Number 0) is 32.596, while the Log Likelihood (2LL) value in (Block Number 1) is 17.425. The impairment of the LL -2 indicates that the null hypothesis is accepted (the hypothesized model is fit with the data) and the regression model is a good model.

c. Coefficient of Determination (Nagelkerke R Square)

The value of Nagelkerke R Square shows the value of the coefficient of determination. The statistical value of Nagelkerke R Square:

Tabel 4

Koefisien Determinasi

\begin{tabular}{|l|r|r|r|}
\hline Step & -2 Log likelihood & Cox \& Snell R Square & Nagelkerke R Square \\
\hline 1 & $17.452^{\mathrm{a}}$ & .396 & .598 \\
\hline
\end{tabular}

The result of statistical test of Nagelkerke R Square value is 0,598 which means that variability of dependent variable can be explained by independent variable equal to 59,8 percent, while the rest 40,2 percent is explained by variable not included in model.

\section{d. Logistic Regression Analysis (Logistic Regression)}

Statistical analysis Logistic Regression, with model $\operatorname{Ln} \frac{G C}{1-G C}=141,9-2,557$ FIDTRESS $-1,714$ DISCLOSURE $+\varepsilon$

Tabel 5

Variables in the Equation

\begin{tabular}{|c|c|c|c|c|c|c|c|}
\hline & & B & S.E. & Wald & df & Sig. & $\operatorname{Exp}(B)$ \\
\hline Step $1^{\mathrm{a}}$ & FIDTRESS & -2.557 & 1.001 & 6.519 & 1 & .011 & .078 \\
\hline \multirow[t]{2}{*}{ Step $2^{b}$} & DICLOSUR & -1.741 & .795 & 4.797 & 1 & .029 & .175 \\
\hline & Constant & 141.923 & 64.703 & 4.811 & 1 & .028 & 4.327E61 \\
\hline
\end{tabular}

a. Hypothesis testing 1 
Based on Logistic Regression calculation result has regression coefficient value equal to $-2,557$ with significance equal to 0,011 . It means that the value of $\mathrm{p}$ value $0.011<0.05$, then $\mathrm{H} 0$ is rejected and $\mathrm{H} 1$ accepted means that financial distress negatively affect the opinion of going Concern.

\section{b. Hypothesis testing 2}

Based on Logistic Regression calculation result has regression coefficient value equal to -1.741 with significance equal to 0,029 . It means that $\mathrm{p}$ value $0,029<0,05$, then $\mathrm{H} 0$ is rejected and $\mathrm{H} 1$ accepted means that disclosure has negative effect on going concern opinion.

\section{DISCUSSION}

\section{The Influence of Financial Distress on the Acceptance of Audit Going Concern}

The result of logistic regression test shows that financial distress variable (FIDSTRESS) has a negative effect on acceptance of going concern audit opinion. The probability value of $p$ value $0,011<0,05$. The value of regression coefficient of financial distress variable -2.557 , direction of research coefficient is negative. It shows that the higher the financial distress, the tendency of companies to accept going concern audit opinion is greater.

Financial distress affect the acceptance of going concern audit opinion, with the opposite direction. The results of this study contradict the study of Santosa et. all (2007) that financial distress does not have a significant effect on the acceptance of going concern audit opinion. The results of this study also contradict the research of Wedari (2007) who found that the financial condition as measured by Altman Z-score prediction has no significant effect on going concern audit opinion.

The results of this study are in line with Arga and Linda's research (2007) which states that the financial condition is used as an indicator of corporate health level. If the company is in bad condition, it is certainly a matter of going concern and most likely the company will accept going concern audit opinion. This research is also in line with research soewiyanto (2012) stating that the financial condition (financial distress) effect on going concern audit opinion.

\section{The Influence of Disclosure on Acceptance of Going Concern Audit Opinion}

The result of logistic regression test showed that the disclosure variable (DICLOSURE) had a negative effect on going concern audit opinion. The probability value of $p$ value $0,029<0,05$. Regression coefficient value of disclosure variable -1.741 , the direction of research coefficient is negative. It shows that the lower the disclosure, the tendency of the company to accept the going concern audit opinion is greater.

These results have an indication that the extent of corporate disclosure will provide additional evidence to the auditor to ensure that there are survival problems experienced by the company so that auditors will issue a going concern audit opinion. Disclosure of the company's management plan or business prospects to overcome the doubt concerning the going concern indicates the inability of the entity in carrying out its operational activities in the future, causing an increased probability of issuing a going concern audit opinion by the auditor.

The results of this study are in line with the research of Haroon et.al (2009), Junaidi and Hartono (2010) and Anindita (2013) stating that disclosure has a negative effect on going concern audit opinion, it shows that the lower the disclosure the higher the company receives audit opinion going concern. However, this study contradicts the research of Adi and Mutmainnah (2012), Verdiana (2013) which states that the disclosure positively affects the going concern audit opinion. Ardiani, et al (2012), Junaidi \& Jogiyanto (2010), and Haron, et al (2009), proved that the disclosure had an effect on the acceptance of going concern auditor's opinion. While Yaqin \& Sari (2015), and Arsianto \& Rahardjo (2013), proved that the disclosure has no effect.

\section{Conclusion}

Based on the results of statistical analysis shows that financial distress negatively affect the giving of going concern opinion on banking companies listing on the Indonesia Stock Exchange. Disclosure negatively affects the giving of going concern opinion of banking companies listing in Indonesia Stock Exchange.

\section{Reference}


1. Altman, Edward I. 1968. Financial Ratios: Discriminan Analysis and The Prediction of Coporate Bankruptcy: Journal of Finance, Vol. 23, Hal: 589- 609.

2. Arga Fajar Santosa and Linda Kusumaning Wedari. 2007. Analysis of Factors Affecting the Acceptance of Audit Going Concern Opinion. JAAI, Volume 11 No.2, December 2007. pp. 141-158.

3. Ardiani, et al. (2012). Effect of Tenure Audit, Disclosure, Cap Size, Debt Default, Opinion Shopping, and Financial Condition Against Audit Opinion Opinion Going Concern on Real Estate Companies and Property at Indonesia Stock Exchange. Journal of Economics. Vol. 20, No. 4.

4. Chen, K. C. W., and B. K. Church. (1996). Going Concern Opinion and the Market's Reaction to Bankruptcy Fillings. The Accounting Review: 117-128

5. Fanny, Margaretta and Saputra, S. (2005). Audit Opinion Going Concern: Study Based on Prediction Model of Bankruptcy, Corporate Growth, and Public Accountant Reputation. National Symposium on Accounting VIII. 966-978.

6. Haron, et.al. (2009). Factors Influencing Auditor's Going Concern Opinion. Asian Academic of Management Journal. Vol. 14, No. 1.

7. Januarti, Indira. (2009). Effect Analysis of Company Factor, Auditor Quality, Company Ownership of Audit Opinion Opinion Going Concern (Manufacturing Company Listed on Indonesia Stock Exchange). Presented at the National Symposium on Accounting XII. Palembang: November 4-6.

8. Junaidi and Jogiyanto Hartono. 2010. Non-Financial Factors on Going Concern Opinion. National Symposium on Accounting XIII.

9. Kurniati W. (2012), Bankruptcy Prediction, Growth and Reputation of Public Accounting Firm Against Audit Opinion Going Concern, Accounting Analysis Journal AAJ 1 (1) 2012, State University of Semarang

10. Mutchler, J.F. (1985). A Multivariate Analysis of The Auditor's Going Concern Opinion Decision. Auditing: A Journal of Accounting Research. Vol. 23, No. 2, Autumn.

11. O‘Reilly, D., M. (2010). Do Investors Percieve The Going Concern Opinion As Useful For Pricing Stocks?. Managerial Auditing Journal. Vol. 25, No. 1.

12. Petronila, T. Anastasia, and Mukhlasin. 2003. Influence of Company Profitability on Timeliness of Reporting of Financial Statements with Audit Opinion as a Moderating Variable. Journal of Economics and Business No. 1 (February): 1725

13. Rahayuningsih, A (2014), Influence of Financial Condition, Auditor Reputation, Disclosure, and Audit Opinion of the previous Year On the disclosure of Going Concern Audit Opinion. Journal of Accounting and Auditing Vol. 11 No. 1 November 2014: P 25-37

14. Ramadhani, Ayu Suci and Niki Lukviarman. (2004). Comparison of Bankruptcy Prediction Analysis Using the First Altman Model, Altman Revision, and Altman Modifications With Company Size and Age As Explanatory Variables (Study on Manufacturing Companies Listed on BEI Business Journal of Figures Vol.13 No. 1. April Hal: 15-28.

15. Retno Windrati S. (2015). Influence of Financial Condition, Audit Delay and Audit Client Tenure on Acceptance of Audit Going Concern Opinion. STIE Perbanas, 
16. Rudyawan, Arry P. and I Dewa Nyoman Badera. 2008. "Going Concern Audit Opinion: Review of Predictions Model of Bankruptcy, Corporate Growth, Leverage, and Auditor Reputation.

17. Santosa, Arga Fajar and Linda Kusumaning Wedari. 2007. "Analysis of Factors Affecting the Acceptance of Audit Opinion Going Concern". Journal of JAAI Volume II No. 2. Hal 141- 158. Semarang: UNIKA Soegijapranata.

18. Setyarno, Indira and Faisal. (2006). Influence of Audit Quality, Company's Financial Condition, Audit Opinion of the previous Year, Corporate Growth Against Audit Going Concern Opinion. National Symposium on Accounting 9 Padang.

19. Soewiyanto, Maria A (2012) Aspects In Giving Opinion Audit Going Concern, Journal Scientific Student Accounting Vol. 1 No. March 2

20. Tucker, Robert R., Ella Mae Matsumura, and K. R. Subramanyam. (2003). Going Concern Judgments: An Experimental Test of The Self-fulfilling Prophecy and Forecast Accuracy. http://www.ssrn.com

21. Yaqin, M \& Sari, M. (2015). The Influence of Financial and Non-Financial Factors on Going Concern Audit Opinion. E-Journal of Accounting Udayana University. Vol. 11, No. 2, ISSN: 23028556. 